as the unit. The decimal system, based on the metric system, was adopted; French instead of Latin legends were used; each piece was stamped with its value; and, thanks to improvements in coining, the coins were more finely executed and more uniform in appearance. The result?-another great coinage under Napoleon I with the 20-franc piece, or "napoleon," emerging as the outstanding French gold coin, which, in its turn, through the nineteenth century set the standard for many other European gold coinages. Now, alas, owing to the upset world conditions both the napoleon and the more famous bouis d'or are merely collectors' pieces.

Shepard Pond, Harvard '10, Ex-President, Boston Numismatic Society.

\title{
December Meeting
}

A joint meeting of the Business Historical Society with the American Historical Association will be held at the Hotel Pennsylvania, New York, on Monday afternoon, December 30. Professor N. S. B. Gras, the vice-president of our Society, will preside, and Professor Robert G. Albion, of Princeton University, will read a paper on "Economic Concentration at New York." The paper will be discussed by Professor Ralph Hidy, Dr. Virginia Harrington, and Mr. Lewis Mumford.

A joint session of the American Historical Association and the Economic History Association will take place on Saturday, December 28, in the afternoon. Professor Abbott Payson Usher, of Harvard University, will preside at this meeting, which will be devoted to the general subject of problems and prospects in economic history. Professor Ralph M. Hower, the clerk of our Society, will discuss the field of business history.

Both these meetings will be of interest and significance to the business historian and to the business man, and it is hoped that a large number of members of the Business Historical Society will be present. Further details may be obtained from the Executive Secretary, Soldiers Field, Boston, Massachusetts. 